\title{
MENINGKATKAN KEMAMPUAN MOTORIK HALUS ANAK MELALUI TEKNIK MENGANYAM DAUN KELAPA DI KELOMPOK B TKN PUTRA MANDIRI KONAWE SELATAN
}

\author{
Silvi Adhitiya Marwah ${ }^{1)}$, Sitti Rahmaniar Abubakar ${ }^{2)}$ \\ ${ }^{1}$ Alumni Jurusan PG-PAUD, Universitas Halu Oleo. Jln. H.E.A Mokodompit, Kendari 93232, \\ Indonesia. \\ ${ }^{2}$ Dosen Jurusan PG-PAUD, Universitas Halu Oleo. Jln. H.E.A Mokodompit, Kendari 93232, \\ Indonesia.
}

E-mail/Telp: Silvyaditya1796@gmail.com / 082292534623

\begin{abstract}
Abstrak
Penelitian ini bertujuan untuk meningkatkan kemampuan motorik halus anak melalui teknik menganyam daun kelapa di kelompok B TKN Putra Mandiri. Subjek dalam penelitian ini adalah guru dan anak yang berjumlah 15 anak. Jenis penelitian ini adalah penelitian tindakan kelas yang dilaksanakan dalam dua siklus. Pengumpulan data dalam penelitian ini menggunakan metode observasi, wawancara dan dokumentasi. Hasil observasi aktivitas mengajar guru pada siklus I diperoleh persentase ketercapaian $80 \%$ sedangkan pada siklus II persentase ketercapaian aktivitas mengajar guru 93,33\%. Hasil aktivitas belajar anak pada siklus I persentase ketercapaian sebesar 86,67 \% sedangkan siklus II persentase ketercapaian aktivitas belajar anak sebesar 93,33\%. Hasil belajar berupa peningkatan kemampuan motorik halus melalui tehnik mengayam duan kelapa sebelum tindakan diperoleh persentase ketercapaian sebesar 34,78 \%, serta mengalami peningkatan pada siklus I dengan ketercapaian sebesar 65,22 \%, dan pada siklus II diperoleh persentase ketercapaian sebesar $91,30 \%$.
\end{abstract}

Kata kunci: Kemampuan Motorik Halus, Menganyam, Anak.

\section{IMPROVING THE FINE MOTORIC ABILITY OF CHILDREN THROUGH THE TECHNIQUE OF WEAVING COCONUT LEAVES IN GROUP B TKN PUTRA MANDIRI}

\begin{abstract}
This study aims to improve children's fine motor skills through the technique of weaving coconut leaves in group B TKN. Putra Mandiri. This research is expected to be able to enrich or add data about the study of science, especially those related to the thirsting of motor skills of children through the technique of weaving coconut leaves. The subjects in this study were teachers and children in Group B TKN. Putra Mandiri, which numbered 15 children. This type of research is classroom action research conducted in two cycles. Data collection in this study using the method of observation, interviews and documentation. Based on the analysis of observational data on teacher teaching activities in the first cycle, the achievement percentage was $80 \%$. Cycle II the percentage of achievement of teacher teaching activities was 93.33\%. Data on the results of children's learning activities in the first cycle of achievement percentage was $86.67 \%$. Cycle II the percentage of achievement of children's learning activities was 93.33\%. Based on the analysis of the results data about the fine motoric abilities of children through the technique of weaving coconut leaves showed an increase, this can be shown in the results before the action and after the action. Before the action obtained the achievement percentage of $34.78 \%$, and experienced an increase in the first cycle with attainment of $65.22 \%$, and in the second cycle obtained an achievement percentage of $91.30 \%$.
\end{abstract}

Keywords: Fine Motor Skills, Weaving, Child

\section{PENDAHULUAN}

Pendidikan anak usia dini adalah suatu upaya pembinaan yang di tujukan kepada anak sejak usia dini yang dilakukan melalui pemberian rangsangan pendidikan untuk membantu pertumbuhan dan perkembangan jasmani dan rohani agar anak memiliki kesiapan dalam memasuki pendidikan dasar kehidupan tahap berikutnya. Sesuai Undang-Undang 
Jurnal Smart PAUD, Vol. 2, No. 2, Juli 2019

Silvi Adhitiya Marwah \& Sitti Rahmaniar Abubakar

Nomor 20 Tahun 2003 tentang Sistem Pendidikan Nasional, pada pasal 28 menyebutkan bahwa Pendidikan Anak Usia Dini (PAUD) diselenggarakan sebelum jenjang pendidikan dasar. Pendidikan anak usia dini dapat diselenggarakan melalui jalur formal, nonformal, serta informal, dan terbagi atas: Tempat Penitipan Anak (TPA), Kelompok Bermain (KB), Taman Kanak-kanak (TK), Raudatul Athfal (RA), atau bentuk lain yang sederajat. Pendidikan anak usia dini di lakukan melalui pemberian rangsangan untuk membantu pertumbuhan serta perkembangan jasmani dan rohani anak agar memiliki kesiapan dalam memasuki pendidikan lebih lanjut (Depdiknas, $2009: 1)$.

Anak usia dini adalah seorang anak yang usianya dibawah enam tahun yang masih mengalami masa pertumbuhan untuk mencapai perkembangan selanjutnya. Menurut Montessori dalam Yuliani (2010: 20) menyatakan bahwa usia keemasan merupakan masa dimana anak mulai peka untuk menerima berbagai stimulasi dan berbagai upaya pendidikan dari lingkungannya baik disengaja maupun tidak disengaja. Pada masa peka inilah terjadi pematangan fungsi fisik dan psikis sehingga anak siap merespon dan mewujudkan semua tugas perkembangan yang diharapkan muncul pada pola perilakunya sehari-hari.

Anak usia dini adalah generasi penerus bangsa yang memiliki karakteristik berbeda dengan anak usia lebih atas sehingga pendidikan anak perlu untuk dikhususkan. Pendidikan Anak Usia Dini (PAUD) telah berkembang dengan pesat dan mendapat perhatian yang luar biasa terutama di negara-negara maju. Oleh karena itu, menurut ilmu tersebut pengembangan kapasitas manusia akan lebih mudah apabila dilakukan sejak usia dini (Suyanto, 2005: 1).

Pembelajaran di Taman Kanak-kanak mengandung enam aspek perkembangan, yaitu perkembangan motorik, perkembangan kognitif, perkembangan bahasa, perkembangan sosial emosional, perkembangan seni, dan perkembangan moral agama. Enam aspek perkembangan dapat dicapai dalam pembelajaran dan aktivitas yang dilakukan pada Taman Kanak-kanak dan pendidik maupun calon pendidik diwajibkan mengetahui dan mengerti perkembangan enam aspek tersebut. Salah satunya aspek motorik, Perkembangan motorik, seiring dengan pertumbuhan fisiknya yang beranjak matang, maka perkembangan motorik anak sudah dapat terkoordinasi dengan baik. Setiap gerakannya sudah selaras dengan kebutuhan atau minat dan bakatnya.

Motorik halus menurut Sujiono (2005: 114) adalah gerakan yang hanya melibatkan bagian-bagian tubuh tertentu saja dan dilakukan oleh otot-otot kecil, seperti keterampilan mmenggunakan jari-jemari tangan dan gerakan pergelangan tangan yang tepat. Oleh karena itu, gerakan ini tidak terlalu membutuhkan tenaga, namun gerakan ini membutuhkan koordinasi mata dan tangan yang cermat.

Sumantri (2005: 143) keterampilan motorik halus adalah pengorganisasian penggunaan sekelompok otot-otot kecil seperti jari-jemari dan tangan yang sering membutuhkan kecermatan dan koordinasi mata dengan tangan.

Dari pengertian tersebut dapat disimpulkan bahwa perkembangan motorik halus adalah kemampuan gerakan yang melibatkan bagian tubuh tertentu saja dan dilakukan oleh otot-otot kecil/ halus. Kemampuan ini memerlukan kecermatan anak yang bisa dilatih dan diajarkan. Oleh karena itu, gerakan ini tidak terlalu membutuhkan tenaga, namun gerakan ini membutuhkan koordinasi mata dan tangan yang cermat. Semakin baiknya gerakan motorik halus anak membuat anak dapat berkreasi seperti menggunting kertas, menggambar, mewarnai serta menganyam. Namun, tidak semua anak memiliki kematangan untuk menguasai kemampuan ini pada tahap yang sama untuk menyiapkan anak pada pendidikan selanjutnya.

Kemampuan motorik dipersiapkan guru untuk meningkatkan kemampuan dan kreativitas anak sesuai dengan tahap perkembangannya. Kemampuan motorik anak sangat berhubungan dengan kemampuan motorik halus yang dimilikinya melalui teknik mengayam. Menganyam untuk anak usia dini tidak dilakukan dengan teknik yang komplek, namun masih dalam tahap teknik dasar menganyam sederhana. Menganyam diajarkan dengan sangat sederhana kepada anak. Kemampuan menganyam dapat mengasah keterampilan motorik halus anak karena menggunakan tangan dan jari-jari demikian juga dengan koordinasi mata. Selain keterampilan motorik halus yang dikembangkan, menganyam juga dapat digunakan sebagai alat untuk melatih logika anak, belajar matematika, dan melatih konsentrasi anak.

Aktivitas menganyam di TKN. Putra Mandiri dikatakan masih perlu dikembangkan 
dengan maksimal karena aktivitas menganyam belum pernah menjadi kegiatan di TKN. Putra Mandiri. Aktivitas menganyam sangat mempengaruhi perkembangan motorik halus anak. Peneliti menggunakan media yang lebih nyata yaitu menganyam dengan menggunakan daun kelapa, agar anak mampu menyadari sejak dini bahwa menganyam pada dasarnya menggunakan media dari dedaunan yang kuat seperti daun pandan, rotan, kelapa dan sebagainya yang bahannya bersifat lebih tahan lama.

Berdasarkan hasil observasi awal yang di lakukan peneliti di TKN. Putra Mandiri, menunjukkan bahwa dari 15 orang anak terdapat 9 anak atau $65,18 \%$ yang tidak mampu meningkatkan motorik halusnya melalui kegiatan mengayam dengan daun kelapa.

Kegiatan menganyam dengan daun kelapa dapat meningkatkan kemampuan motorik halus tangan serta gerakan tangan anak. Pada kegiatan menganyam ini dapat melatih emosi dan koordinasi gerak mata anak karena kegiatan menganyam ini anak dituntut untuk lebih sabar dan lebih teliti dalam mengerjakan dan menyelesaikan kegiatan. Kegiatan menganyam juga merupakan kegiatan gerakan keterampilan yaitu dalam menyusun lungsi dan pakan. Kegiatan ini dilakukan melalui praktik langsung oleh anak-anak karena pembelajarannya keahlian dalam hal keterampilan hanya bisa diperoleh dengan cara praktik. Pembelajaran motorik pada anak tidak boleh terlepas dari prinsip-prinsip belajar anak usia dini yang salah satunya yaitu belajar melalui bermain.

Kegiatan menganyam dapat dikatakan berhasil apabila anak dapat menghasilkan karya anyaman.Sebelum anak melakukan kegiatan menganyam hendaknya diberikan latihan-latihan dan pengenalan media bahan dan alat sekaligus penggunaannya terlebih dahulu agar anak tidak kaku saat melakukan kegiatan menganyam

\section{METODE}

Jenis penelitian yang digunakan dalam penelitian ini adalah PenelitianTindakan Kelas (classroom action research). Penelitian Tindakan Kelas adalah pencermatan yang dilakukan oleh orang-orang yang terlibat di dalamnya (guru, peserta didik, dan kepala sekolah) dengan menggunakan metode refleksi diri dan bertujuan untuk melakukan penelitian di berbagai aspek pembelajaran (Suyadi, 2013: 22).

Subjek dalam penelitian ini adalah guru dan anak didik di Kelompok B Taman kanak- kanak Negeri Putra Mandiri, dengan jumlah anak 15 orang yang terdiri 9 anak laki-laki dan 6 anak perempuan.

Adapun faktor-faktor yang akan diteliti dan diamati dalam penelitian ini adalah sebagai berikut: 1) Faktor anak didik mengamati anak didalam kelas yang mengikuti proses pembelajaran dalam upaya meningkatkan kemampuan motorik halus anak melalui teknik menganyam daun kelapa dan hasil belajar anak berupa peningkatan motorik halus anak melalui tehnik mengayam. 2) Faktor guru yakni mengamati dan memperhatikan segala aktivitas guru, yang mempersiapkan dan melaksanakan segala sesuatunya yang dibutuhkan dalam kegiatan proses pembelajaran tentang meningkatkan kemampuan motorik halus anak melalui teknik menganyam daun kelapa di kelompok B TKN. Putra Mandiri.

Data yang diperoleh dari penelitian ini adalah data kualitatif dan data kuantitatif. Data kualitatif digunakan untuk menghimpun data tentang pelaksanaan proses pembelajaran yang dilaksanakan oleh guru dan anak. Data kualitatif diperoleh melalui lembar observasi. Sedangkan data kuantitatif menghimpun data tentang peningkatan motorik halus anak melalui melalui teknik menganyam untuk yang diperoleh melalui lembar instrumen/evaluasi yang dilakukan pada setiap pertemuan dan diakhir siklus tindakan.

Penilaian terhadap kemampuan motorik halus yang dapat diperhatikan dalam kegiatan menganyam dengan daun kelapa yang dicontohkan guru, dievaluasi dengan mengacu pada pedoman pemberian penilaian dalam satuan pendidikan TK yakni dengan diberikan dalam bentuk simbol-simbol seperti $* * * *=\mathrm{BSB}$ (anak yang mengalami peningkatan kemampuan motorik halus dengan baik dan lancar tanpa bimbingan guru), $* * *=\mathrm{BSH}$ (memperolah kemampuan tapi masih dibimbing), $* *=\mathrm{MB}$ (memiliki kemampuan dengan dibimbing secara langsung oleh guru), dan $*=\mathrm{BB}$ (tidak memiliki kemampuan dan masih dalam pengawasan dan bimbingan guru. (Depdiknas, 2004: 11).

Indikator kinerja dalam penelitian ini ditetapkan oleh TKN. Putra Mandiri, yang terdiri dari indikator proses pembelajaran dan indikator hasil (nilai) anak didik. Dari segi indikator proses pembelajaran, tindakan dikatakan berhasil apabila minimal $90 \%$ proses pelaksanaan tindakan sesuai dengan skenario pembelajaran, baik yang dilakukan oleh guru 
maupun anak didik. Dari segi indikator hasil, tindakan dikatakan berhasil apabila anak didik telah mencapai nilai berkembang sesuai harapan (BSH) dan berkembang sangat baik (BSB) minimal $75 \%$ baik secara individual maupun klasikal.

\section{HASIL DAN PEMBAHASAN}

Sebelum kegiatan penelitian ini dilaksanakan, peneliti terlebih dahulu melakukan pertemuan awal dengan kepala sekolah Taman Kanak-Kanak Putra Mandiri yaitu, pada tanggal 05 februari 2018. Pertemuan ini bermaksud untuk menyampaikan tujuan dari peneliti yaitu mengadakan penelitian sekaligus melakukan observasi awal di Taman KanakKanak Putra Mandiri. Selanjutnya, kepala TK mengarahkan peneliti untuk berdiskusi dengan guru kelompok B. Setelah itu, peneliti melakukan observasi awal di Taman KanakKanak Putra Mandiri khususnya kelompok B.

Sehari sebelum melakukan observasi awal, langkah pertama yang dilakukan peneliti yaitu terlebih dahulu menyiapkan media yang akan digunakan dalam kegiatan peningkatan motorik halus melalui kegiatan menganyam. Berdasarkan hasil observasi dan dilanjutkan dengan wawancara singkat dengan guru kelompok B. yaitu untuk meningkatkan kemampuan motorik halus anak melalui teknik menganyam daun kelapa di kelompok B TKN. Putra Mandiri.

Berdasarkan observasi dan wawancara yang dilaukan peneliti menunjukan bahwa dalam kegiatan peningkatan motorik halus melalui kegiatan menganyam di kelompok B TKN. Putra Mandiri masih sangat rendah yaitu berada dalam kategori Mulai Berkembang (MB) dan Belum Berkembang (BB).

Berdasarkan permasalahan yang dihadapi tersebut, maka peneliti berusaha merancang bentuk kegiatan pembelajaran yang menarik dan menyenangkan bagi anak untuk meningkatkan motorik halus anak melalui teknik menganyam daun kelapa pada nak kelompok B TKN. Putra Mandiri. Selanjutnya, peneliti bersama guru kelompok B TKN.Putra Mandiri sepakat berkolaborasi dan menjadi mitra dalam kegiatan penelitian ini. Setelah itu, mengacu pada program semester peneliti menyusun Rencana Pelaksanaan Pembelajaran Mingguan (RPPM) yang kemudian dijabarkan menjadi Rencana Pelaksanaan Pembelajaran Harian (RPPH), dimana didalamnya memuat waktu pelaksanaan kegiatan, indikator, kegiatan pembelajaran, nilai-nilai pembelajaran, alat, sumber belajar dan penilaian perkembangan anak.

Penelitian dilakukan dengan tindakan siklus I yang terdiri dari 4 kali pertemuan dan mengikuti empat tahapan kegiatan yaitu perencanaan, pelakanaan tindakan, observasi dan evaluasi, dan refleksi. Hal-hal yang dilakukan dalam tahap ini adalah menyiapkan RPPH dan RPPM, media yang dibutuhkan, lembar observasi anak dan guru serta alat evaluasi/penilaian.

Tindakan pada siklus I pertemuan I, peneliti melaksanakan pembelajaran sesuai dengan Rencana Program Pembelajaran Harian (RPPH) yang telah dipersiapkan terlebih dahulu dengan tema rekreasi yang dilaksanakan pada tanggal 4, 5, 7 dan 8 Mei 2018. Pada tahap ini, tindakan penelitian dilaksanakan di kelompok B TKN. Putra Mandiri, dengan jumlah anak 15 orang yang terdiri 9anak laki-laki dan 6 anak perempuan. Pelaksanaan tindakan siklus I ini dilaksanakan sebanyak 4 kali pertemuan. Adapun indikator yang harus dicapai anak didik pada setiap pertemuan yaitu anak dapat memilah daun lungsi dan pakan sebagai media pembelajaran, anak mampu menyusun lungsi secara vertical, anak mampu menyisipkan pakan secara horizontal, anak dapat menganyam dengan baik.

Pada kegiatan awal ini telah menjadi kebiasaan anak dan guru, setiap pagi melaksanakan apel pagi dihalaman sekolah yang dipimpin oleh guru, guru mengatur anak-anak untuk berbaris dengan rapi dan sesuai dengan kelas masing-masing serta tak lupa juga anakanak menyanyikan beberapa lagu, kemudian mengucapkan salam dan masuk kelas secara berurut. Selanjutnya guru membuka proses pembelajaran dengan mengucapkan salam, setelah itu anak-anak bernyanyi beberapa lagu.

Pada kegiatan inti guru menjelaskan tentang tema yang dibawakan yaitu tema alam semesta, sub tema yaitu gejala alam dan bercakap-cakap tentang gejala alam. Setelah memberikan apersepsi dan tanya jawab dengan anak, guru menjelaskan mengenai tugas pada hari tersebut. Kegiatan pertama adalah kegiatan menggambar pelangi. Guru dan peneliti membagikan gambar dan pensil warna kepada masing-masing anak. Pada kegiatan menggambar ini anak memawarnai gambar pegunungan dan pelangi menggunakan pensil warna.

Kegiatan akhir, guru mengajak anak untuk membuat kesimpulan tentang kegiatan 
yang telah dilakukan yaitu menceritakan tentang kegiatan apa yang telah dilakukan hari ini dan menceritakan tentang apa yang dirasakan pada anak saat melakukan kegiatan. Setelah itu guru memberikan informasi tentang kegiatan yang akan dilakukan besok, kemudian guru mempersiapkan anak-anak untuk membaca doa keluar kelas dan doa keselamatan dunia akhirat dan lain-lain serta mengucapkan salam.

Tindakan siklus I pertemuan II dilaksanakan pada hari Selasa tanggal 5 Mei 2018 dari pukul 07.00-11.00 WITA di kelompok B TKN. Putra Mandiri. Setiap pagi melaksanakan apel pagi dihalaman sekolah yang dipimpin oleh guru, guru mengatur anak-anak untuk berbaris dengan rapi dan sesuai dengan kelas masing-masing serta tak lupa juga anakanak menyanyikan beberapa lagu, kemudian mengucapkan salam dan masuk kelas secara berurut. Selanjutnya guru membuka proses pembelajaran dengan mengucapkan salam, setelah itu anak-anak bernyanyi.

Pada kegiatan inti ini dipertemuan II dalam meningkatkan kemampuan motorik halus anak, guru bercerita terlebih dahulu kegiatan apa yang kemarin telah dilaksanakan, guru menjelaskan tentang macam-macam gejala alam, selanjutnya guru menyuruh anak untuk mengulang kembali macam-macam gejala alam dan akibatnya. Setelah itu guru menyuruh anakanak merenggangkan kedua tangannya dengan cara menggoyangkan pergelangan tangannya, guru memperkenalkan daun kelapa sekaligus fungsi dan kegunaannya kepada anak-anak serta menjelaskan kegiatan lainnya yang sudah terencana dalam RPPH.

Kegiatan akhir, guru mengajak anak untuk membuat kesimpulan tentang kegiatan yang telah dilakukan yaitu menceritakan tentang kegiatan apa yang telah dilakukan hari ini dan menceritakan tentang apa yang dirasakan pada anak saat melakukan kegiatan. Setelah itu guru memberikan informasi tentang kegiatan yang dilakukan besok, kemudian guru mempersiapkan anak untuk pulang dan membimbing anak untuk mengucapkan doa keselamatan dunia akhirat serta doa keluar kelas, doa naik kendaraan darat dan lain-lain, serta mengucapkan salam.

Tindakan siklus I pertemuan III dilaksanakan pada hari Rabu tanggal 7 Mei 2018 dari pukul 07.00-11.00 WITA di kelompok B TKN. Putra Mandiri. setiap pagi melaksanakan apel pagi dihalaman sekolah yang dipimpin oleh guru, guru mengatur anak-anak untuk berbaris dengan rapi dan sesuai dengan kelas masingmasing serta tak lupa juga anak-anak menyanyikan beberapa lagu, kemudian mengucapkan salam dan masuk kelas secara berurut. Selanjutnya guru membuka proses pembelajaran dengan mengucapkan salam, setelah itu anak-anak bernyanyi.

Pada kegiatan inti guru bercerita terlebih dahulu kegiatan apa yang kemarin telah dilaksanakan. Setelah itu guru menjelaskan tentang macam-macam gejala alam dan bercakap-cakap tentang bagian-bagian dari longsor, selanjutnya guru menyuruh anak untuk mengulang kembali macam-macam gejala alam dan sebab akibat longsor.

Anak-anak kemudian diajak untuk menghitung lembaran daun kelapa yang dibagikan, guru mencotohkan daun kelapa diatur di atas meja lalu anak mengikuti gurunya. Peneliti mulai mengajarkan anak dalam menganyam sederhna yaitu memasukkan pakan ke sisi lungsi.

Kegiatan akhir, guru mengajak anak untuk membuat kesimpulan tentang kegiatan yang telah dilakukan yaitu menceritakan tentang kegiatan apa yang telah dilakukan hari ini dan menceritakan tentang apa yang dirasakan pada anak saat melakukan kegiatan menganyam. Setelah itu guru memberikan informasi tentang kegiatan yang dilakukan besok, kemudian guru mempersiapkan anak untuk pulang dan membimbing anak untuk mengucapkan doa kedua orang tua serta doa ke luar kelas, doa naik kendaraan darat dan lain-lain, serta mengucapkan salam.

Tindakan siklus I pertemuan IV dilaksanakan pada hari Kamis tanggal 8 Mei 2018 dari pukul 07.00-11.00 WITA di kelompok B TKN. Putra Mandiri. Setiap pagi melaksanakan apel pagi dihalaman sekolah yang dipimpin oleh guru, guru mengatur anak-anak untuk berbaris dengan rapi dan sesuai dengan kelas masing-masing serta tak lupa juga anakanak menyanyikan beberapa lagu, kemudian mengucapkan salam dan masuk kelas secara berurut. Selanjutnya guru membuka proses pembelajaran dengan mengucapkan salam, setelah itu anak-anak bernyanyi.

Pada kegiatan inti guru bercerita terlebih dahulu kegiatan apa yang kemarin telah dilaksanakan. Setelah itu guru menjelaskan tentang macam-macam gejala alam dan bercakap-cakap tentang hujan, selanjutnya guru menyuruh anak untuk mengulang kembali macam-macam gejala alam dan mengenal hujan. 
Jurnal Smart PAUD, Vol. 2, No. 2, Juli 2019

Silvi Adhitiya Marwah \& Sitti Rahmaniar Abubakar

Pertemuan kali ini guru membagikan kembali potongan daun kelapa yang terdiri dari pakan dan lungsi. Guru dan peneliti memberikan contoh menganyam sederhana di depan anakanak.

Kegiatan akhir, guru mengajak anak untuk membuat kesimpulan tentang kegiatan yang telah dilakukan yaitu menceritakan tentang kegiatan apa yang telah dilakukan hari ini dan menceritakan tentang apa yang dirasakan pada anak saat melakukan kegiatan menganyam.

Setelah itu guru memberikan informasi tentang kegiatan yang dilakukan besok, kemudian guru mempersiapkan anak untuk pulang dan membimbing anak untuk mengucapkan doa keselamatan dunia akhirat serta doa keluar kelas, doa naik kendaraan darat dan lain-lain, serta mengucapkan salam.Selama proses pembelajaran berlangsung, guru sebagai observer mengamati jalannya pembelajaran dengan menggunakan lembar observasi untuk guru dan lembar observasi untuk anak. Kegiatan observasi dilakukan bersamaan dengan pelaksanaan tindakan untuk setiap pertemuan pada siklus I.

Hasil analisis observasi guru sesuai dengan lembar observasi sebanyak 15 aspek yang diamati. Pada siklus I skor yang dicapai oleh guru dari 15 aspek terdapat 12 aspek yang dicapai sebesar $80 \%$ diantaranya :(1) guru mempersiapkan anak untuk belajar; (2)guru mengucapkan salam; (3) guru menyampaikan tujuan pembelajaran; (4)guru memulai pelajaran;(5) guru menyiapkan media berkaitan dengan kegiatan menganyam;(6) guru menjelaskan materi pembelajaran tentang menganyam;(7) guru meminta anak mengikuti aturan-aturan dalam menganyam;(8) guru menjelaskan materi tentang tatacara menganyam; (9) guru meminta anak mengikuti aturan-aturan dalam menganyam; (10) guru memperlihatkan cara menganyam;(11) guru mengamati anak menganyam;(12) guru memberikan kesempatan kepada anak untuk menceritakan pengalaman saat menganyam. Sedangkan yang tidak tercapai 3 aspek atau 20 $\%$ diantaranya : (1) guru mengarahkan anak untuk berdoa sebelum belajar; /gejala alam; (2) guru mereview kembali kegiatan yang telah dilakukan;(3) guru memberi kesimpulan tentang kegiatan yang dilakukam hari ini dan memberi salam dilakukan.

Data hasil aktivitas mengajar guru pada siklus I dapat digambarkan dalam histogram berikut.

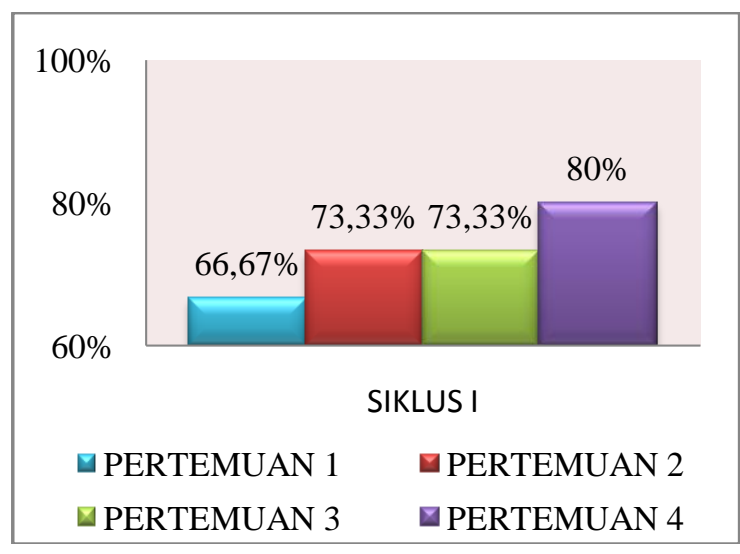

Gambar 1. Histogram Hasil Analisis Aktivitas Mengajar Guru Siklus I

Analisis hasil pengamatan anak didik sesuai dengan lembar observasi pada siklus I sebanyak 15 aspek yang diamati diharapkan terrcapai, tetapi yang tercapai sebanyak 13 aspek (86,67\%) diantaranya: (1) anak mempersiapkan diri untuk belajar; (2) anak menjawab salam dari guru; (3) anak bernyanyi; (4) anak menyebutkan media berkaitan dengan kegiatan menganyam; (5), anak mendengarkan materi tentang menganyam; (6) anak mampu mengikuti aturanaturan dalam menganyam; (7) anak mendengarkan materi tentang tatacara menganyam; (8) anak mampu memperhatikan guru cara menganyam; (9) anak diberikan kesempatan untuk menganyam; (10) anak mampu berdiskusi cara menyelesaikan anyaman; (11) anak menceritakan kegiatan yang telah dilakukan; (12)anak diberikan kesempatan untuk menceritakan pengalaman saat menganyam; (13) anak bersama guru berdoa dan mengucapkan salam setelah melakukan kegiatan. Sedangkan yang tidak tercapai 2 aspek $(13,33 \%)$ diantaranya yaitu: (1) anak mendengarkan appersepsi dengan tema/sub tema alam semesta/gejala alam; (2) anak mendengarkan guru untuk berdoa sebelum belajar.

Hasil analisis belajar anak didik dapat digambarkan dalam histogram berikut ini:

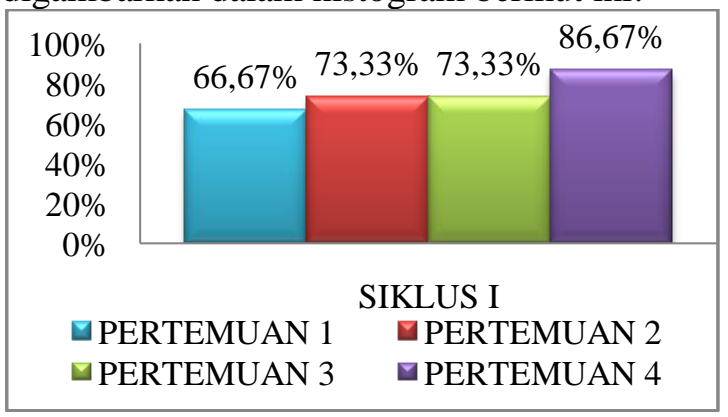

Gambar 2 Histogram Hasil Analisis Aktivitas Belajar Anak Didik Siklus I 
Berdasarkan histogram tersebut aktivitas hasil belajar anak pada siklus I menunjukkan bahwa dari 15 aspek yang diamati dalam proses pembelajaran aspek yang terlaksana 13 aspek dengan persentase $86,67,42 \%$, sedangkan yang tidak terlaksana 2 aspek dengan persentase $13,33 \%$, dengan demikian hasil aktivitas belajar anak pada siklus I belum maksimal sedangkan standar ketercapaian aktivitas belajar anak yang harus dicapai $\geq 75 \%$ sehingga dapat dikatakan berhasil.

Peneliti yang bekerjasama dengan guru kelompok B TKN. Putra Mandiri melakukan evaluasi atau penilaian pada akhir siklus. Hal ini dilakukan untuk mengetahui perkembangan peningkatan kemampuan motorik halus anak melalui teknik menganyam daun kelapa berdasarkan tema/subtema. Evaluasi dilakukan Berkembang Sangat Baik (BSB), Berkembang Sesuai Harapan (BSH), Mulai Berkembang (MB) dan Belum Berkembang (BB). Untuk mendapatkan informasi sejauh mana kemampuan motorik halus anak setelah dilakukan tindakan siklus I.

Tabel 1. Nilai Klasikal pada Siklus I

\begin{tabular}{lll}
\hline \multicolumn{1}{c}{ Kategori } & Jumlah Anak & Persentase \\
(BSB) & 4 & $21,73 \%$ \\
(BSH) & 6 & $43,47 \%$ \\
(MB) & 3 & $26,08 \%$ \\
(BB) & 2 & $8,69 \%$ \\
Jumlah & 15 & $100 \%$ \\
\hline
\end{tabular}

(Sumber : Diolah Dari Data Penelitian, Mei 2018)

Berdasarkan hasil yang diperoleh pada Tabel 1. terlihat bahwa secara klasikal kegiatan meningkatkan kemampuan motorik halus anak, sebagian besar anak sudah dapat melaksanakan kegiatan dengan baik yaitu $70 \%$ anak memperoleh nilai BSB dan BSH namun belum mencapai indikator kinerja yang ditetapkan yaitu 75\% anak memperoleh nilai BSB dan BSH. Oleh karena itu, guru dan peneliti mendiskusikan kekurangan-kekurangan apa saja yang terdapat pada pelaksanaan tindakan siklus I untuk kemudian diperbaiki dan dilaksanakan pada siklus II.

Dari hasil observasi, maka beberapa hal yang harus diperbaiki adalah guru masih kurang mampu mengelola kelas, masih kurang dalam menyampaikan tujuan pembelajaran yang dilakukan hari ini, guru tidak mengorganisir waktu belajar sesuai dengan apa yang telah direncanakan pada skenario pembelajaran dan guru masih canggung dalam pelaksanaan kegiatan pembelajaran, sehingga anak didik belum mampu menerapkan media daun kelapa untuk kegiatan pembelajaran melalui teknik menganyam.

Kegiatan yang dilakukan oleh peneliti pada siklus II sama dengan tindakan yang dilakukan pada siklus I meliputi perencanaan, pelaksanaan tindakan, pengamatan/observasi, dan refleksi. Mengacu pada data hasil temuan observasi, evaluasi dan refleksi pada tahap kegiatan siklus I, maka peneliti bersama guru kelompok B sepakat untuk melaksanakan kegiatan untuk tindakan siklus II dengan lebih optimal dan persiapan yang lebih baik lagi, agar kekurangan-kekurangan yang terdapat pada tindakan siklus I dapat diminimalisir. Dalam perencanaan tindakan ini peneliti kembali menyiapkan hal-hal yang akan dilakukan dalam pembelajaran.

Pelaksanaan tindakan siklus II pertemuan I dilaksanakan pada hari Rabu, tanggal 9 Mei 2018 pada pukul 07.00-11.00 WITA. Setiap pagi melaksanakan apel pagi dihalaman sekolah yang dipimpin oleh guru, guru mengatur anak-anak untuk berbaris dengan rapi dan sesuai dengan kelas masing-masing serta tak lupa juga anakanak menyanyikan beberapa lagu, kemudian mengucapkan salam dan masuk kelas secara berurut. Selanjutnya guru membuka proses pembelajaran dengan mengucapkan salam, setelah itu anak-anak bernyanyi.

Pada kegiatan inti, guru terlebih dahulu mempersiapkan media menganyam, guru kembali menjelaskan dan memberikan contoh menganyam sederhana sampai anak benar-benar mengerti cara menganyam yang benar. Hal tersebut dimaksudkan agar anak-anak dapat mengikutikegiatan dengan lebih tertib daripada pada siklus sebelumnya. Guru segera mengatur anak pada tempat duduknya masing-masing, kemudian setelah terkondisikan anak diajak bergerak sesuai dengan instruksi guru. Anak mulai melakukan kegiatan menganyam dengan tenang. Dari hasil pengamatan, anak-anak terlihat sangat antusias serta terlihat lebih tertib dan menikmati kegiatan tersebut. Anak-anak yang pada siklus sebelumnya masih terlihat emosi dan tidak sabar dalam menyelesaikan anyamannya. Hal tersebut terlihat dari semakin baik dan lancar menganyam.

Kegiatan akhir, guru mengajak anak untuk membuat kesimpulan tentang kegiatan yang telah dilakukan yaitu menceritakan tentang kegiatan apa yang telah dilakukan hari ini dan menceritakan tentang apa yang dirasakan pada 
anak saat melakukan kegiatan menganyam. Setelah itu guru memberikan informasi tentang kegiatan yang dilakukan besok, kemudian guru mempersiapkan anak untuk pulang dan membimbing anak untuk mengucapkan doa keselamatan dunia akhirat serta doa keluar kelas , doa naik kendaraan darat dan lain-lain, serta mengucapkan salam.

Pelaksanaan tindakan siklus II pertemuan II dilaksankan pada hari Kamis,10 Mei 2018, pada pukul 07.00-11.00 WITA. Setiap pagi melaksanakan apel pagi dihalaman sekolah yang dipimpin oleh guru, guru mengatur anak-anak untuk berbaris dengan rapi dan sesuai dengan kelas masing-masing serta tak lupa juga anakanak menyanyikan beberapa lagu, kemudian mengucapkan salam dan masuk kelas secara berurut. Selanjutnya guru membuka proses pembelajaran dengan mengucapkan salam, setelah itu anak-anak bernyanyi.

Pada kegiatan inti guru terlebih dahulu mempersiapkan media menganyam, guru kembali menjelaskan dan memberikan contoh menganyam sederhana sampi anak benar-benar mengerti cara menganyam yang benar.Hal tersebut dimaksudkan agar anak-anak dapat mengikutikegiatan dengan lebih tertib daripada pada siklus sebelumnya. Guru segera mengatur anak pada tempat duduknya masing-masing, kemudian setelah terkondisikan anak diajak bergerak sesuai dengan instruksi guru. Anak mulai melakukan kegiatan menganyam dengan tenang. Dari hasil pengamatan, anak-anak terlihat sangat antusias serta terlihat lebih tertib dan menikmati kegiatan tersebut. Anak-anak yang pada siklus sebelumnya masih terlihat emosi dan tidak sabar dalam menyelesaikan anyamannya. Hal tersebut terlihat dari semakin baik dan lancarnya anak menganyam.

Kegiatan akhir, guru mengajak anak untuk membuat kesimpulan tentang kegiatan yang telah dilakukan yaitu menceritakan tentang kegiatan apa yang telah dilakukan hari ini dan menceritakan tentang apa yang dirasakan pada anak saat melakukan kegiatan menganyam. Setelah itu guru memberikan informasi tentang kegiatan yang dilakukan besok, kemudian guru mempersiapkan anak untuk pulang dan membimbing anak untuk mengucapkan doa keselamatan dunia akhirat serta doa keluar kelas , doa naik kendaraan darat dan lain-lain, serta mengucapkan salam.

Pelaksanaan tindakan siklus II pertemuan III dilaksankan pada hari Jumat, 11 Mei 2018 pada pukul 07.00-11.00 WITA. Setiap pagi melaksanakan apel pagi dihalaman sekolah yang dipimpin oleh guru, guru mengatur anak-anak untuk berbaris dengan rapi dan sesuai dengan kelas masing-masing serta tak lupa juga anakanak menyanyikan beberapa lagu, kemudian mengucapkan salam dan masuk kelas secara berurut. Selanjutnya guru membuka proses pembelajaran dengan mengucapkan salam, setelah itu anak-anak bernyanyi.

Pada kegiatan inti guru terlebih dahulu mempersiapkan media menganyam, guru kembali menjelaskan dan memberikan contoh menganyam sederhana sampi anak benar-benar mengerti cara menganyam yang benar.Hal tersebut dimaksudkan agar anak-anak dapat mengikuti kegiatan dengan lebih tertib daripada pada siklus sebelumnya. Guru segera mengatur anak pada tempat duduknya masing-masing, kemudian setelah terkondisikan anak diajak bergerak sesuai dengan instruksi guru. Anak mulai melakukan kegiatan menganyam dengan tenang. Dari hasil pengamatan, anak-anak terlihat sangat antusias serta terlihat lebih tertib dan menikmati kegiatan tersebut.Anak-anak yang pada siklus sebelumnya masih terlihat emosi dan tidak sabar dalam menyelesaikan anyamannya.Hal tersebut terlihat dari semakin baik dan lancarnya anak menganyam.

Kegiatan akhir, guru mengajak anak untuk membuat kesimpulan tentang kegiatan yang telah dilakukan yaitu menceritakan tentang kegiatan apa yang telah dilakukan hari ini dan menceritakan tentang apa yang dirasakan pada anak saat melakukan kegiatan menganyam. Setelah itu guru memberikan informasi tentang kegiatan yang dilakukan besok, kemudian guru mempersiapkan anak untuk pulang dan membimbing anak untuk mengucapkan doa keselamatan dunia akhirat serta doa keluar kelas , doa naik kendaraan darat dan lain-lain, serta mengucapkan salam.

Pelaksanaan tindakan siklus II pertemuan IV dilaksankan pada hari Sabtu, 12 Mei 2018 pada pukul 07.00-11.00 WITA. Setiap pagi melaksanakan apel pagi dihalaman sekolah yang dipimpin oleh guru, guru mengatur anak-anak untuk berbaris dengan rapi dan sesuai dengan kelas masing-masing serta tak lupa juga anakanak menyanyikan beberapa lagu, kemudian mengucapkan salam dan masuk kelas secara berurut. Selanjutnya guru membuka proses pembelajaran dengan mengucapkan salam, setelah itu anak-anak bernyanyi.

Pada kegiatan inti guru menanyakan kabar anak dan melakukan absensi. Guru 
terlebih dahulu mempersiapkan media menganyam, guru kembali menjelaskan dan memberikan contoh menganyam sederhana sampi anak benar-benar mengerti cara menganyam yang benar. Hal tersebut dimaksudkan agar anak-anak dapat mengikutikegiatan dengan lebih tertib daripada pada siklus sebelumnya. Guru segera mengatur anak pada tempat duduknya masing-masing, kemudian setelah terkondisikan anak diajak bergerak sesuai dengan instruksi guru. Anak mulai melakukan kegiatan menganyam dengan tenang. Dari hasil pengamatan, anak-anak terlihat sangat antusias serta terlihat lebih tertib dan menikmati kegiatan tersebut.Anak-anak yang pada siklus sebelumnya masih terlihat emosi dan tidak sabar dalam menyelesaikan anyamannya.Hal tersebut terlihat dari semakin baik dan lancarnya anak menganyam.

Kegiatan akhir, guru mempersilahkan anak-anak untuk duduk kembali dan mengarahkan anak untuk mencuci tangan sebelum makan. Kemudian, masuk pada kegiatan makan bersama, sebelum kegiatan makan bersama dimulai guru membimbing anak untuk membaca doa sebelum makan. Setelah anak selesai makan guru membimbing anak berdoa sesudah makan dan mempersilahkan anak untuk bermain diluar ruangan. Selanjutnya, anak masuk kedalam ruangan untuk bersiap pulang, sebelum jam pelajaran ditutup, guru mengajak anak untuk membuat kesimpulan tentang kegiatan yang telah dilakukan yaitu menceritakan tentang kegiatan apa yang telah dilakukan hari ini dan menceritakan tentang apa yang dirasakan pada anak saat melakukan kegiatan menganyam. Setelah itu guru memberikan informasi tentang kegiatan yang dilakukan besok, kemudian guru mempersiapkan anak untuk pulang dan membimbing anak untuk mengucapkan doa keselamatan dunia akhirat serta doa keluar kelas , doa naik kendaraan darat dan lain-lain, serta mengucapkan salam.

Hasil analisis observasi guru sesuai dengan lembar observasi sebanyak 15 aspek yang diamati. Pada siklus II skor yang dicapai oleh guru dari 15 aspek terdapat 14 aspek dengan persentase 93,33 diantaranya: (1) guru mempersiapkan anak untuk belajar; (2) guru Mengucapkan salam; (3) guru Mengarahkan anak untuk berdoa sebelum belajar; (4)guru memulai pelajaran;(5) guru menyiapkan media berkaitan dengan kegiatan menganyam ;(6) guru menjelaskan materi pembelajaran tentang menganyam;(7) guru meminta anak mengikuti aturan-aturan dalam menganyam;(8) guru menjelaskan materi tentang tatacara menganyam (9) guru meminta anak mengikuti aturan-aturan dalam menganyam; (10) guru memperlihatkan cara menganyam;(11) guru mengamati anak menganyam;(12) guru memberikan kesempatan kepada anak untuk menceritakan pengalaman saat menganyam; (12) guru mereview kembali kegiatan yang telah dilakukan; (13) guru memberikan kesimpulan tentang kegiatan yang dilakukan hari ini daan salam penutup; (14) melakukan appersepsi dengan tema/sub tema alam semesta/gejala alam.

Sedangkan yang tidak tercapai sebanyak 1 aspek dengan persentase 6,67\% yaitu : (1) guru memberikan umpan balik dan informasi tentang kegiatan esok hari;

Hasil Analisis aktivitas mengajar guru siklus II dapat digambarkan dalam histogram berikut:

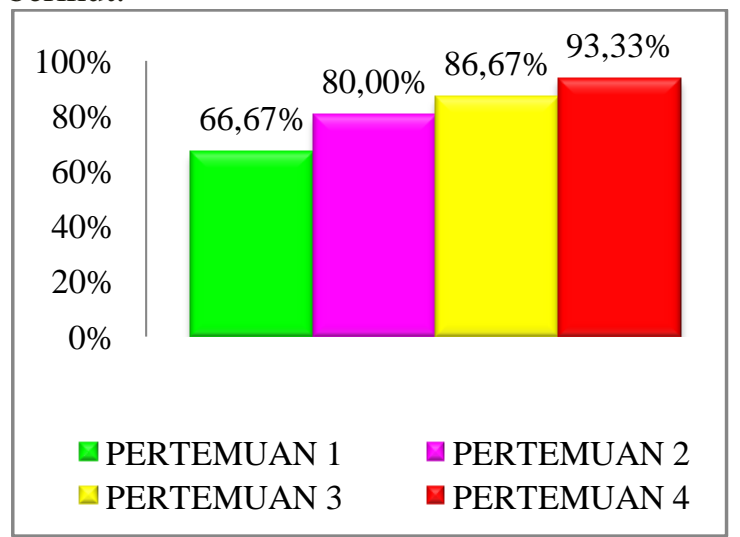

Gambar 3. Histogram Hasil Analisis Aktivitas mengajar Guru siklus II

Observasi terhadap anak didik meliputi mendengarkan guru menyampaikan tujuan pembelajaran, mendengarkan cerita guru dengan tertib, anak melakukan tanya jawab dengan guru tentang permainan tebak gambar, dan mendengarkan kesimpulan terhadap kegiatan yang dilakukan.

Analisis hasil pengamatan anak didik sesuai dengan lembar observasi pada siklus II sebanyak 15 aspek yang diamati diharapkan tercapai, yang tercapai sebanyak 14 aspek dengan persentase 93,33 \% di antaranya:(1) anak mempersiapkan diri untuk belajar; (2) anak menjawab salam dari guru; (3) anak bernyanyi; (4) anak menyebutkan media berkaitan dengan kegiatan menganyam; (5)anak mendengarkan materi tentang menganyam; (6) anak mampu mengikuti aturan-aturan dalam menganyam; (7) anak mendengarkan materi tentang tatacara menganyam; (8) anak mampu memperhatikan 
guru cara menganyam; (9) anak diberikan kesempatan untuk menganyam; (10) anak mampu berdiskusi cara menyelesaikan anyaman; (11) anak menceritakan kegiatan yang telah dilakukan; (12)anak diberikan kesempatan untuk menceritakan pengalaman saat menganyam; (13) anak bersama guru berdoa dan mengucapkan salam setelah melakukan kegiatan. Sedangkan yang tidak tercapai sebanyak 1 aspek $(6,67 \%)$ diantaranya: (1) anak mendengarkan guru yang membimbing untuk berdoa sebelum belajar.

Hasil analisis aktivitas hasil belajar anak didik pada siklus II dapat digambarkan dalam histogram berikut:

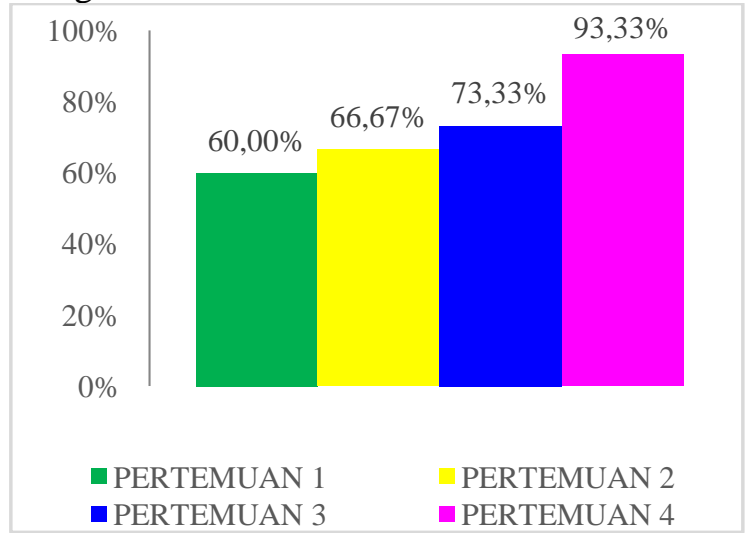

\section{Gambar 4. Histogram Hasil Analisis Aktivitas Belajar Anak Siklus II}

Berdasarkan histogram tersebut aktivitas belajar anak pada siklus II diketahui 15 aspek yang diamati, terdapat 14 aspek yang tercapai sedangkan yang tidak tercapai sebanyak 1 aspek, dengan demikian persentase keberhasilan belajar anak tersebut sebesaar 93,33\% dan yang tidak tercapai $6,67 \%$ maka dapat dikatakan telah berhasil mencapai indikator.

Pada tahap pengamatan atau observasi, peneliti senantiasa mencatat segala apa yang diperoleh pada pelaksanaan tindakan siklus II, nilai tersebut diperoleh berdasarkan kemampuan anak pada kegiatan yang bertujuan untuk meningkatkan kemampuan motorik halus anak melalui teknik menganyam di kelompok B TKN. Putra Mandiri.

Tabel 2. Nilai Klasikal pada Siklus II

\begin{tabular}{ccc}
\hline Kategori & $\begin{array}{c}\text { Jumlah } \\
\text { Anak }\end{array}$ & $\begin{array}{c}\text { Persentase } \\
(\%)\end{array}$ \\
$(\mathrm{BSB})$ & 3 & $27,75 \%$ \\
$(\mathrm{BSH})$ & 10 & $47,82 \%$ \\
$(\mathrm{MB})$ & 2 & $26,08 \%$ \\
(BB) & 0 & $0 \%$ \\
Jumlah & 15 & $100 \%$ \\
\hline
\end{tabular}

Berdasarkan Tabel 2 tersebut hasil evaluasi pada siklus II dapat diketahui bahwa kemampuan motorik halus anak pada TKN. Putra Mandiri pada siklus II mengalami peningkatan, karena dapat dilihat telah terjadi peningkatan yang cukup baik pada Kategori BSB $(* * * *)$ terdapat 3 anak dengan persentase $27,75 \%$ sedangkan pada kategori BSH (***) terdapat 10 anak dengan persentase 47,82 \%, sedangkan pada kategori MB $(* *)$ terdapat 2 anak dengan persentase 26,08 \% dan pada kategori BB (*) tidak terdapat anak dengan persentase $0 \%$. Dengan demikian setelah adanya tindakan pada siklus II persentase kemampuan motorik halus anak meningkat menjadi 91,30\% sehingga dapat dikatakan penelitian telah berhasil mencapai indikator kinerja, sehingga penelitian dapat di hentikan

\section{SIMPULAN DAN SARAN}

\section{Simpulan}

Hasil observasi aktivitas mengajar guru pada siklus I diperoleh persentase ketercapaian $80 \%$ sedangkan pada siklus II persentase ketercapaian aktivitas mengajar guru 93,33\%. Hasil aktivitas belajar anak pada siklus I persentase ketercapaian sebesar 86,67 \% sedangkan siklus II persentase ketercapaian aktivitas belajar anak sebesar 93,33\%. Hasil belajar berupa peningkatan kemampuan motorik halus melalui tehnik mengayam duan kelapa sebelum tindakan diperoleh persentase ketercapaian sebesar $34,78 \%$, serta mengalami peningkatan pada siklus I dengan ketercapaian sebesar $65,22 \%$, dan pada siklus II diperoleh persentase ketercapaian sebesar 91,30 \%. Dengan demikian dapat disimpulkan bahwa kemampuan motorik halus anak dapat di ditingkatkan melalui kegiatan mengayam dengan daun kelapa di kelompok B TKN Putra Mandiri KonaweSelatan.

\section{Saran} bagi :

Adapun saran dalam penelitian ini adalah

1. Bagi guru yakni dalam pembelajaran sosial emosional, khususnya untuk meningkatkan kemampuan motorik halus anak guru dapat menerapkan aktivitas menganyam.

2. Bagi sekolah yakni hasil penelitian sebaiknya menjadi alat pengambilan kebijakan dalam menentukan program pengembangan kemampuan motorik halus anak di TKN. Putra Mandiri. Selain itu 
sekolah juga perlu memberikan dan memfasilitasi kegiatan pembelajaran yang sifatnya berkelompok agar kemampuan social emosional dan motorik halus anak dalam berinteraksi dapat terarah dengan baik, khususnya kegiatan menganyam.

3. Bagi peneliti selanjutnya yakni penerapan aktivitas menganyam daun kelapa dapat dipakai sebagai referensi bagi penelitian terkait dengan aspek-aspek perkembangan anakyang lain seperti aspek perkembangan kognitif, social emosional, maupun fisikmotorik.

\section{DAFTAR PUSTAKA}

Aisyah, Siti dkk. 2007. Perkembangan Dan Konsep Dasar Perkembangan Anak Usia Dini. Jakarta: Universitas Terbuka.

Depdiknas. 2009. Pedoman Pembelajaran Motorik Halus di Taman Kanak-kanak. Jakarta: Direktorat Pembinaan Taman Kanak-kanak dan Sekolah Dasar.

Dewi, Rosmala. 2005. Berbagai Masalah Anak Taman Kanak-kanak. Jakarta: Departemen Pendidikan.

Endang Purwanti dan Nur Widodo. 2005. Perkembangan Peserta Didik. Malang:Universitas Muhamadiyah Malang.

Hurlock, B. Elizabeth. 1978. Perkembangan Anak jilid 1. (Terjemahan: Med Meitasari Tjandrasa bad Muchlihah Zarkasih). Jakarta: PT. Gelora Aksara

Pratama. Irfan, Mohamad dkk. 2016. Studi Klasifikasi Tujuh Gerakan Tangan Sinyal electromyography (EMG) Menggunakan Metode Pattern Recognition. Jurnal Teknik Mesin S-1. 4 (3).

Kartini Kartono. 1995. Psikologi Anak (Psikologi Perkembangan). Bandung: Mandar Maju.

Pamadhi Hajar dan Evan Sukardi S. 2008. Seni Ketrampilan Anak. Jakarta: Universitas Terbuka.

Pusat Bahasa Depdiknas. 2008. Kamus Besar Bahasa Indonesia (Edisi Keempat). Jakarta: Pusat Bahasa.

Sujiono, Bambang. 2005. Mencerdaskan Periaku Anak Usia Dini. Jakarta: Elex Media Komputindo.
Sukamti Rini Endang. 2007. Diktat Perkembangan Motorik. Yogyakarta: FIK UNY.

Sumanto. 2005. Pengembangan kreativitas seni rupa anak TK. Jakarta: Depdiknas. 